\title{
THE EFFECT OF TROPICAL AND OTHER ENVIRONMENTAL FACTORS ON STATURE AND SUBCUTANEOUS FAT IN KAMPALA NURSERY SCHOOL CHILDREN
}

BY

\author{
H. F. WELBOURN \\ From Mulago Hospital, Kampala, Uganda
}

(RECEIVED FOR PUBLICATION JULY 18, 1960)

The adaptation of European children to life in tropical climates is a subject fraught with emotional and political undercurrents. The literature on the subject can be divided into two main groups: that concerning children living in areas where the European immigrant population is becoming assured, such as tropical Australia and Central America where the favourable aspects are emphasized (Cilento, 1925; Grenfell Price, 1935) and Colonial areas such as East Africa where the position is less secure and reports express anxiety (Mackinnon, 1923; De Boer, 1924; Roberts, 1949). The 'lassitude and mental dulness' of European school children in Kenya described in the very early papers is still discussed, although lassitude among children in those days could almost certainly have been attributed to malaria and other parasitic diseases which were far more prevalent then than now. All the authors quoted found that tropical European school children were taller at all ages than children in England and that the onset of the puberty growth spurt was earlier, especially in girls. The reaction to this feature was one of approval on the part of the Australian authors and of anxiety ('depressing effects of a hot house atmosphere') on the part of the East African authors.

This paper is concerned, not with older children around whom an emotional rearguard action is still being fought, but with children of nursery school age (4 to $5 \frac{1}{2}$ years) in Kampala. Parents of these children were circularized and interviewed to find out whether they wished to bring any special complaints regarding their children to the notice of the school doctor. Almost all expressed some form of anxiety as to the suitability of the climate to their children's health. Many complained that their children had no appetite in Kampala although they ate satisfactorily while on leave in Great Britain.
It occurred to me that this may have been a normal reaction to climate and that in a tropical climate one might expect to feel more comfortable with a thinner layer of subcutaneous fat. Very little work has been done on this aspect of adjustment to climate, although there is some evidence that body weight and basal metabolism tend to be lower in hot climates (Roberts, 1953).

An attempt was therefore made to compare the height, weight and amount of subcutaneous fat (based on arm measurements and skin fold using a Harpenden caliper) of European children aged 4-5 $\frac{1}{2}$ years in Kampala with children of the same age in England (Acheson, Kemp and Parfit, 1955; Hammond, 1955) and with Kampala African children of the same ages.

\section{Method}

Height, weight, upper arm length, mid-arm circumference and triceps skinfold thickness were recorded for each child using a method which has been described in another paper (McFie and Welbourn, 1960). This method differed from that usually followed because the measurements were taken with the arm flexed to a right angle. This gave arm circumference readings about 2-5 $\mathrm{mm}$. higher than those taken with the arm extended. Because of this difference in method the arm circumference readings were not included in this report. The skinfold measurements were taken with the muscle freely mobile under the fat and the arm relaxed, and in these conditions there was no difference between the readings in extension and right-angle flexion.

\section{The Children and their Environment}

The European children, all from Great Britain, were resident in Kampala for periods ranging from 21-40 months, spending three to 10 months on leave in the United Kingdom at the end of each period in Kampala. Their parents were in either pro- 
fessional or skilled occupations. For purposes of comparison the heights of children in the Oxford Survey (Acheson et al., 1955) were used. The children in the Oxford Survey were also of superior social class (only $16 \%$ were in classes IV and V) and thus, although the Kampala families probably had a slightly higher standard of living than those in Oxford, the two groups were comparable.

The African children were all of the highest socio-economic class. They were attending an expensive private nursery school and their parents were all in professional employment. In spite of this, their standard of living was on the whole not so high as that of the European children and although all the children were having milk daily, a varied diet and regular meals, their diet was still for traditional reasons a little overbalanced in favour of carbohydrate. None of the children had enlarged spleens, and none were suffering from the effects of tropical parasitic diseases. They were all of the same tribe (Ganda).

The climate of Kampala is not extremely tropical. Indoor temperatures range from 75 to $80^{\circ} \mathrm{F}$. throughout the year; rainfall is moderate and evenly distributed through the year. The countryside is always green and there are no seasonal changes. The altitude is $3,700 \mathrm{ft}$. above sea level. European children run about everywhere in the sun without hats; they get far hotter than their parents and seem to enjoy it. Their parents often hanker after sharp air and bracing winds, and when this is so they are inclined to worry about the possible ill effects of a tropical climate.

\section{Results}

Heights and Weights. Fig. 1 shows the distribution of heights and weights of European and African children in Kampala compared with heights and weights of children in the Oxford Survey. Since all the children in the present series were weighed at different ages, no attempt was made to calculate average weights at different ages. Instead, individual readings of weight and height for age were plotted in relation to mean heights and weights of children in the Oxford Survey: the Oxford Survey weights and heights for age were plotted showing the mean (M) and the values of one, two and three standard deviations above $(+1,+2$ and +3$)$ and below $(-1,-2$ and -3$)$ the mean. Individual readings in the present series were plotted on this graph and the number of readings in relation to the mean were counted as follows: Above the mean; $\mathbf{M}$ to +1 s.d.; +1 s.d. to +2 s.d.; +2 s.d. to +3 s.d.: and below the mean: $M$ to -1 s.d.; -1 s.d. to -2 s.d.; -2 s.d. to -3 s.d. The numbers of readings in each group are shown as histograms in Fig. 1.

Comparing Kampala European children with children in the Oxford Survey, the weights of the children of both sexes and the heights of the girls were similar in Kampala and Oxford (Fig. 1). There was a slight superiority in height of the Kampala European boys over the Oxford boys which was only just significant and represented a difference in mean height about 0.5 in. $(1.3 \mathrm{~cm}$.). Comparing the Kampala European with Kampala African, there was a marked superiority in both height and weight of the European children of both sexes, representing a difference in mean height of about $1 \cdot 25$ in. $(3 \cdot 2 \mathrm{~cm}$.).

Arm Length. Arm length ranged from $193 \mathrm{~mm}$. at 4 years to $208 \mathrm{~mm}$. at 5 years. There was no difference between African and European children or between the sexes.

Subcutaneous Fat. The Table shows the average triceps skinfold readings of Kampala African and European children compared with children in England measured by Hammond (1955). Comparing Kampala European children with children in England, the readings for the girls in England and Kampala were similar, but the boys in Kampala had slightly (just significantly) less subcutaneous fat than boys in London. The readings for the Kampala African children of both sexes were 0.5 $\mathrm{mm}$. lower than the Kampala European children.

\section{Discussion}

In a study of pre-school age children in Durban, Phillips (1953) emphasized that the economic group to which a child belonged was far more important in determining the stature of the child than the ethnic group. In another study in Durban, Lewis (1959) emphasized the importance of social and cultural factors influencing the health of children of this age. Phillips (1953) found that the heights and weights of European pre-school age children in Durban were similar to those of European children of the same income groups in other parts of the world, though his upper-income group children were slightly taller and heavier than upperincome group children in sources quoted by Phillips and also than European children in the present series.

In neither of the above studies was the question of adaptation to climate discussed, although Phillips noted that there was no difference in stature between lower income group children in Johannesburg, Melbourne and London. In the present 

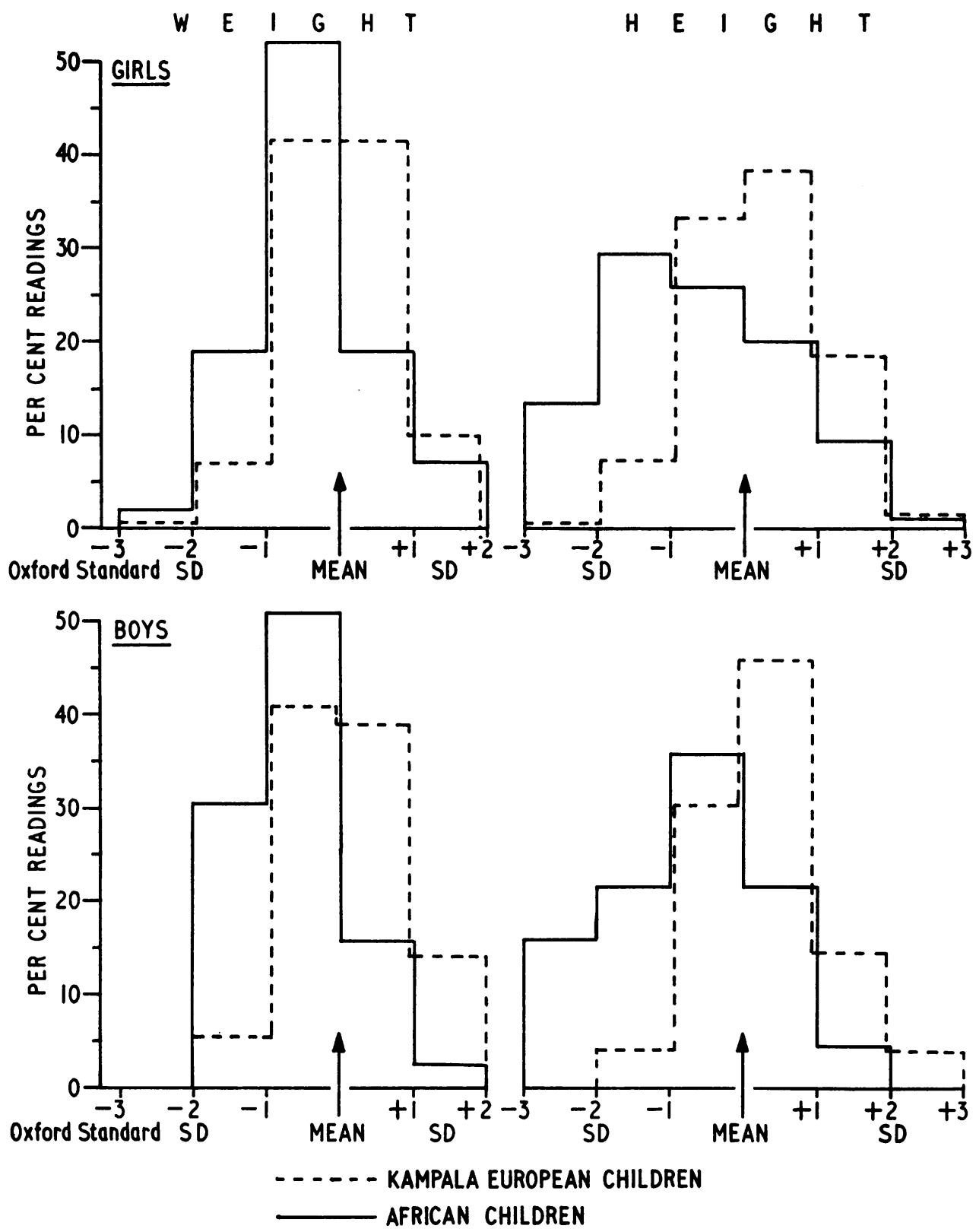

FIG. 1.-Distribution of heights and weights of European and African children in Kampala with Oxford Standard.

series the heights, weights and skinfold measurements of European children in Kampala were practically similar to those of children in England. The Kampala European boys were slightly taller and had slightly less subcutaneous fat than children in England, but these differences were only just significant and probably not important. The lack of appetite and failure to grow well reported by parents of Kampala European children were undoubtedly subjective impressions based on the parents' attitude to conditions of living in Kampala. No objective evidence was found either of the ill effects of a tropical environment or of possible beneficial adaptations to the environment on the part of the children.

It has already been shown (Welbourn, 1955) that 
TABLE

SKINFOLD THICKNESSES OF AFRICAN AND EUROPEAN CHILDREN IN KAMPALA COMPARED WITH CHILDREN IN ENGLAND

\begin{tabular}{|c|c|c|c|c|c|c|c|c|}
\hline & \multicolumn{2}{|c|}{ Kampala African } & \multirow{3}{*}{$\begin{array}{c}\text { Kampala } \\
\text { Boys }\end{array}$} & \multirow{3}{*}{$\begin{array}{c}\text { European } \\
\text { Girls }\end{array}$} & \multicolumn{4}{|c|}{ England (Hammond) } \\
\hline & \multirow{2}{*}{ Boys } & \multirow{2}{*}{ Girls } & & & \multicolumn{2}{|c|}{ Boys } & \multicolumn{2}{|c|}{ Girls } \\
\hline & & & & & $4-5 \mathrm{yrs}$ & $5-6$ yrs & $4-5$ yrs & $5-6$ yrs \\
\hline $\begin{array}{l}\text { Total children measured } \\
\text { Average skinfold thickness (mm.) } \\
\text { Standard deviation } \quad . .\end{array}$ & $\begin{array}{l}82 \\
7 \cdot 3 \\
1 \cdot 50\end{array}$ & $\begin{array}{l}78 \\
8 \cdot 0 \\
1 \cdot 75\end{array}$ & $\begin{array}{l}101 \\
8 \cdot 8 \\
1 \cdot 42\end{array}$ & $\begin{array}{l}100 \\
9 \cdot 5 \\
1 \cdot 85\end{array}$ & $\stackrel{43}{9 \cdot 34}$ & $\stackrel{49}{9 \cdot 13}$ & $\begin{array}{l}44 \\
10 \cdot 24\end{array}$ & $\begin{array}{l}45 \\
9.42\end{array}$ \\
\hline
\end{tabular}

the increase in weight and height of Uganda African infants and pre-school children is poor compared with children in Western countries, and that this difference is less marked among children of highly educated families. This is well illustrated in Fig. 2 which shows increase in weight from birth to 6 years of African boys of different socio-economic groups compared with boys of the same ages in England. Weight curves for girls have not been shown; except that the girls were a little lighter, the curves for the girls were exactly similar to those for boys shown in Fig. 2. The curve for 'class 1' African children was derived from figures published by Jelliffe and Dean (1959) together with weights of children attending child welfare clinics and nursery schools.

The weight curve of these children was above that for children of the same tribe of lower socioeconomic groups attending ordinary village child welfare clinics: the difference first became apparent at 3 to 6 months, and thereafter there was a difference of about 2 to $3.5 \mathrm{lb}$. $(0.9$ to $1.6 \mathrm{~kg}$.). The difference was most marked during the 18 - to 30 -month age period, because during this time Uganda African children suffered most severely from malnutrition, infections and traumatic experiences associated with

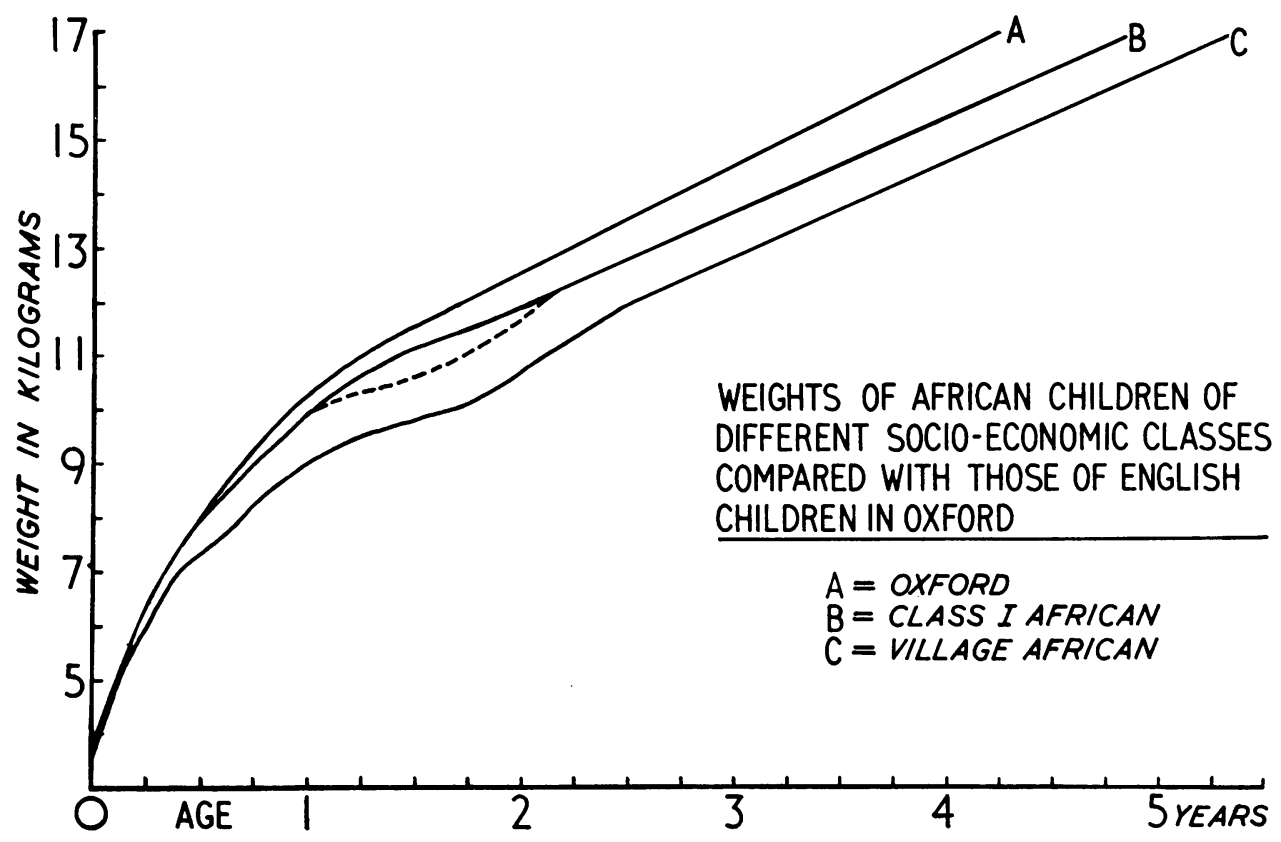

Fig. 2.-Weights of African boys of different socio-economic classes compared with those of English children in Oxford Survey.

$\mathrm{A}=$ Oxford Survey.

B = Class 1 African standard curve. True curve shown by dotted line.

$\mathrm{C}=$ Village African. 
weaning and maternal separation (Geber and Dean, 1957; Welbourn, 1959). Even the 'class 1' African children gained weight less well in this age period: the true weight curve showed a dip maximal at $0.5 \mathrm{~kg}$. below the standard curve at 20 months (Burgess, 1960), which was not shown on the standard figures (Jelliffe and Dean, 1959). This dip showed that even the children in 'class 1' were underfed, probably because for cultural reasons they were offered food less frequently and regularly than children in England, and the main meal of the day was likely to be overbalanced in favour of bulky carbohydrate.

The nursery schoolchildren in the present series were shorter, lighter, had less subcutaneous fat and lower muscle estimate values than English children of the same ages in Kampala. It cannot be known with certainty how far these differences were attributable to ethnic characteristics. Neither is it certain whether lack of subcutaneous fat is advantageous in a tropical climate. Certainly many of the African nursery schoolchildren gave an impression of toughness and wiriness, and it is common experience in inter-racial children's sports in Kampala that wiry little African and Asian children usually have the advantage over their heavier European contemporaries. Although the African nursery schoolchildren were from the best possible socio-economic group, their standard of living was still not as high as that of European children in Kampala. Socio-economic and cultural factors which had affected the child throughout life and particularly during the period after weaning were probably more important than ethnic or climatic factors in determining the differences observed between European and African children in Kampala.

\section{Summary}

Heights, weights, upper-arm length, circumferences and skinfold were measured in European and African children aged from 4 to $5 \frac{1}{2}$ years attending Kampala nursery schools. Measurements of Kampala European children were found to be almost the same as those of children in England. The African children were shorter, lighter and had less subcutaneous fat than the European children. The arm lengths of the two groups were similar.

It was suggested that the growth of the Kampala European children was satisfactory and that the differences between the European and African children were due more to socio-economic and cultural than to climatic factors.

I wish to record my thanks to Dr. C. P. Welter and Mr. Paul Mogambi of the Department of Mathematics, Makerere University College, Kampala, for their help with the compilation of statistics and for preparing the histograms shown in Fig. 1.

\section{REFERFNCES}

Acheson, R. M., Kemp, F. H. and Parfit, Jessie (1955). Height, weight and skeletal maturity in the first five years of life. Lancet, 1, 691 .

Burgess, H. J. L. (1960). The Medical Research Council's rural child welfare clinic. E. Afr. med. J., 37, 396.

Cilento, R. W. (1925). The white man in the tropics. Commonwealth of Australia Dept. Health Service Publ. No. 7.

De Boer, H.S. (1924). A survey of European children of school-going age attending schools in Nairobi, Kenya Colony. E. Afr. med. J., 1, 265.

Geber, M. and Dean, R. F. A. (1957). Gesell tests on African children. Pediatrics, 20, 1055.

Grenfell Price, A. (1935). White settlement in the Panama Canal Zone. Geogr. Rev., 25, 1

Hammond, W. H. (1955). Measurement and interpretation of subcutaneous fat, with norms for children and young adult males. Brit. J. prev. soc. Med., 9, 201.

Jelliffe, D. B. and Dean, R. F. A. (1959). Protein-calorie malnutrition in early childhood. J. trop. Pediat., 5, 96.

Lewis, J. B. (1959). A study of the health of a pre-school age-group in an African urban community. Ibid., $5,10$.

Mackinnon, M. (1923). Education in its relation to the physical and mental development of European children of school age in Kenya. J. trop. Med. Hyg., 26, 136.

McFie, J. and Welbourn, H. F. (1960). In the press.

Phillips, H. T. (1953). Some social and ethnic variations in the physique of South African nursery school children. Arch. Dis. Childh., 28, 226.

Roberts, D. F. (1953). Body weight, race and climate. Amer. J. Phys. Anthrop., 11, 533.

Roberts, J. I. (1949). Biological studies on Kenya school children. J. trop. Med. Hyg., 52, 225.

Welbourn, H. F. (1955). The danger period during weaning. J. trop. Pediat., 1, 34.

(1959). Backgrounds and follow-up of children with kwashiorkor. Ibid., 5, 84. 